\title{
Endophyte-infection reduces leaf dehydration of ryegrass and tall fescue plants under moderate water deficit
}

\author{
L. HE ${ }^{1}$, J.-H.B. HATIER ${ }^{2}$, S.D. CARD ${ }^{2}$ and C. MATTHEW ${ }^{1}$ \\ ${ }^{1}$ Institute of Agriculture and Environment, Massey University, Private Bag 11222, Palmerston North, New Zealand \\ ${ }^{2}$ AgResearch Ltd, Grasslands Research Centre, Tennent Drive, Palmerston North 4442, New Zealand
}

1.he@massey.ac.nz

\begin{abstract}
Drought stress is one of the limiting factors in perennial ryegrass growth and development. In order to investigate the drought responses among different cultivars and evaluate the role of fungal endophyte in modifying drought responses, a glasshouse experiment was conducted using ryegrass cultivars 'Alto' and 'Banquet II', and a Mediterranean tall fescue cultivar, 'Grasslands Flecha' as contrast with the two ryegrass cultivars. Under drought stress 'Flecha' had a higher stomatal conductance and transpiration rate than the two ryegrass cultivars, and also significantly greater deeproot allocation. Endophyte-infected plants exhibited reduced leaf dehydration under stress compared with endophyte-free plants. Under stress, endophyte-free plants displayed significantly lower relative water content and a more negative leaf water potential and osmotic potential than well-watered endophyte-free plants, whereas endophyte-infected plants displayed smaller and non-significant changes when subjected to water deficit stress. Endophyte-infected plants also had less deep-root allocation than endophyte-free plants. The results of this study increase understanding of the relationship between endophytes and their ryegrass or tall fescue hosts under drought stress.
\end{abstract}

Keywords: deep-root allocation, Epichloë, gas exchange parameters, Neotyphodium, plant water relations, Lolium perenne

\section{Introduction}

Perennial ryegrass (Lolium perenne L.) is one of the major components of New Zealand pastures; however, the growth and development of this species can be significantly constrained by regular severe drought events (Clark 2011). Improved persistence and production of ryegrass cultivars under summer drought conditions is becoming increasingly important due to the intensification of farming systems (Matthew et al. 2010) and the rise in our planet's average atmospheric temperature.

Drought tolerance is defined as the possession of physiological and biochemical adaptations that enable plant tissues to cope with water deficit (Clarke \& Durley 1981). Mechanisms of drought tolerance include reducing water loss or maintaining water uptake to delay dehydration (e.g. increased stomatal resistance and/or increased root density and depth), and maintenance of turgor in order to tolerate dehydration (e.g. by osmotic adjustment) (Turner 1986).

Currently, concerns are being expressed about the capacity of more recently released perennial ryegrassendophyte combinations to persist and perform in the modern dairy farming context (Parsons et al. 2011). Epichloë fungal endophytes, including asexual morphs formerly classified in the form genus Neotyphodium, have an essential role in pasture systems since selected strains can protect their host grasses from a range of insect pests (Popay \& Hume 2011). It has also been shown that under drought conditions Epichloë endophytes induce responses in their grass hosts including plant phenotype adaptations to avoid drought and biochemical and physiological adaptations for drought tolerance (Malinowski \& Belesky 2000) although the mechanisms are poorly understood. However, endophyte effects on drought tolerance of perennial ryegrass are multifarious; for example, Cheplick (2004) claimed that the symbiotic relationship between endophyte and host plants benefits the fungus rather than the host under drought stress, while Hesse (2003) and Kane (2011) showed that endophytes can improve the drought tolerance of their host plants by inducing increased root dry weight, root:shoot ratio, and increased tiller number and height, green shoot mass, and total yield.

In the present study, we imposed water deficit stress in order to investigate the drought responses of ryegrass and tall fescue (Schedonorus arundinaceus (Schreb.) Dumort, formerly Festuca arundinacea (Schreb.)) cultivars to evaluate the role of Epichloë fungal endophytes in modifying drought responses. Our hypotheses were that these three cultivars may have some differences in drought responses and that endophyte would play a role in modifying some of the responses to drought stress.

\section{Methods}

\section{Experimental design}

The glasshouse experiment was a factorial $3 \times 2 \times 2$ 
design with three grass cultivars, two endophyte statuses (endophyte-infected and endophyte-free) and, two water treatments (well-watered and drought stressed). Three genotypes of each cultivar were used as replicates for each treatment, making 36 plants in total. Plants were obtained from another project, where seeds were sown in September 2011.

\section{Plant material and plant culture}

Two ryegrasses cultivars were studied: 'Alto' (diploid, L.perenne), and 'Banquet II' (a tetraploid certified as a long term hybrid ryegrass, Lolium $x$ bouchianum, but has agronomic performance similar to that of a perennial). Initially, these ryegrass cultivars were infected with endophyte strains AR37 and Endo5 (AR5), respectively. A Mediterranean tall fescue cultivar 'Grasslands Flecha', infected with endophyte strain AR542 was also studied. Plants with three to four tillers were transferred on 26 September 2012 to PVC pots $(100 \mathrm{~cm}$ high, $10 \mathrm{~cm}$ diameter $)$ lined with a polythene plastic tube filled with soil to $5 \mathrm{~cm}$ from the pot rim. Pots in treatment groups of six (three cultivars with and without endophyte) were placed in $200 \mathrm{~L}$ drums with a plastic tap fitted at the bottom. Soil used in the experiment was obtained from the B horizon of a Manawatu silt loam, with a field capacity

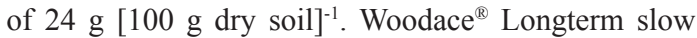
release fertiliser ( $\mathrm{N}: \mathrm{P}: \mathrm{K}=18: 2.2: 8.3$ ) was added to soil as a rate of $6 \mathrm{~g} / 100 \mathrm{~L}$ soil to ensure adequate nutrient supply. Temperature was monitored and recorded every ten minutes during the experiment from 26 Sep 2012 to 8 January 2013. The average glasshouse temperature

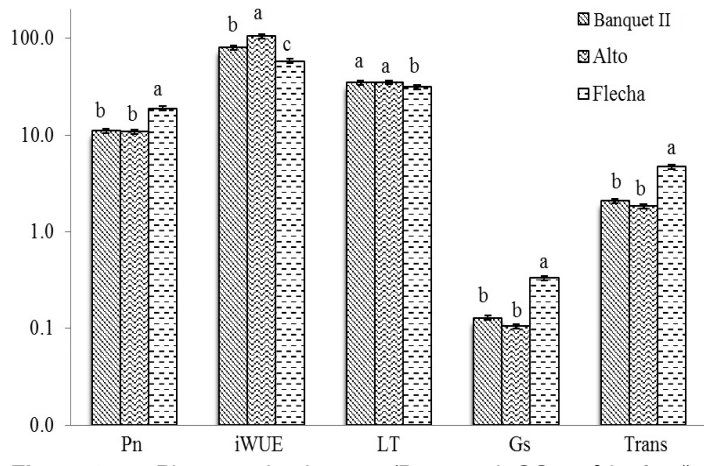

Figure 1 Photosynthesis rate $\left(\mathrm{Pn}, \mu \mathrm{mol} \mathrm{CO}_{2} \mathrm{~m}^{2}\right.$ leaf $\left.\mathrm{s}^{-1}\right)$, instantaneous water use efficiency (iWUE), leaf temperature $\left(\mathrm{LT},{ }^{\circ} \mathrm{C}\right)$, stomatal conductance (Gs, $\mathrm{mmol} \mathrm{H}_{2} \mathrm{O} \mathrm{m}^{2}$ leaf $\mathrm{s}^{-1}$ ) and transpiration rate (Trans, mmol $\mathrm{H}_{2} \mathrm{O} \mathrm{m}^{2}$ leaf $\mathrm{s}^{-1}$ ) of the three cultivars. Y-axis is logarithmic to account for the different scaling of the various data. Columns with different letters are significantly different at $\mathrm{P} \leq 0.05$. Vertical bars are standard errors.

was $21.8^{\circ} \mathrm{C}$ with the daily maximum and minimum temperatures averaging $36^{\circ} \mathrm{C}$ and $8^{\circ} \mathrm{C}$, respectively. Time with temperature above $30^{\circ} \mathrm{C}$ was 37.2 hours in total during the experiment.

\section{Endophyte assessment and elimination}

To obtain genetically identical pairs of endophyteinfected and endophyte-free plants, the endophyte was eliminated from clonal replicates of infected plants using the fungicide benomyl as described by Latch \& Christensen (1982) with immuno-detection (Simpson et al. 2012) and microscopy examination (Latch \&

Table 1 Effects of water treatments, and water treatment interaction between endophyte status and soil water content (SWC) of three soil depths (D1 0-30 cm, D2 30-60 cm, and D3 60-100 cm) and plant daily water uptake.

\begin{tabular}{|c|c|c|c|c|}
\hline & \multicolumn{4}{|c|}{ Water treatment } \\
\hline & \multicolumn{2}{|c|}{ Control } & \multicolumn{2}{|c|}{ Stress } \\
\hline & E- & $\mathrm{E}+$ & E- & $\mathrm{E}+$ \\
\hline \multirow[t]{2}{*}{$\begin{array}{l}\text { SWC-D1 } \\
(\%)\end{array}$} & $\begin{array}{c}0.119 \mathrm{a} \\
(0.037)\end{array}$ & 0.118 a $(0.0231)$ & $\begin{array}{c}0.080 \mathrm{~b} \\
(0.029)\end{array}$ & $0.107 \mathrm{ab}(0.032)$ \\
\hline & \multicolumn{2}{|c|}{$0.118(0.033) \mathrm{A}$} & \multicolumn{2}{|c|}{$0.093(0.033) \mathrm{B}$} \\
\hline \multirow[t]{2}{*}{$\begin{array}{l}\text { SWC-D2 } \\
(\%)\end{array}$} & $\begin{array}{c}0.191 \mathrm{a} \\
(0.032)\end{array}$ & 0.161 a $(0.057)$ & $\begin{array}{c}0.099 \mathrm{~b} \\
(0.048)\end{array}$ & $\begin{array}{c}0.148 \text { a } \\
(0.051)\end{array}$ \\
\hline & \multicolumn{2}{|c|}{$0.176(0.047) \mathrm{A}$} & \multicolumn{2}{|c|}{$0.123(0.054) \mathrm{B}$} \\
\hline \multirow[t]{2}{*}{$\begin{array}{l}\text { SWC-D3 } \\
(\%)\end{array}$} & $\begin{array}{c}0.263 \mathrm{a} \\
(0.021)\end{array}$ & 0.245 a (0.054) & $\begin{array}{c}0.099 \mathrm{c} \\
(0.066)\end{array}$ & $\begin{array}{l}0.167 b \\
(0.088)\end{array}$ \\
\hline & \multicolumn{2}{|c|}{$0.254(0.041) \mathrm{A}$} & \multicolumn{2}{|c|}{$0.134(0.083) \mathrm{B}$} \\
\hline \multirow[t]{2}{*}{ Daily water use $\left(\mathrm{kg} \mathrm{pot}^{-1}\right)$} & $\begin{array}{c}0.216 a \\
(0.083)\end{array}$ & 0.186 a (0.095) & $\begin{array}{c}0.051 \mathrm{~b} \\
(0.022)\end{array}$ & $\begin{array}{r}0.037 \mathrm{~b} \\
(0.021)\end{array}$ \\
\hline & \multicolumn{2}{|c|}{$0.201(0.088) A$} & \multicolumn{2}{|c|}{$0.044(0.022) \mathrm{B}$} \\
\hline
\end{tabular}

Note: The standard deviations (SD) of means are shown in brackets. Small letters in each row indicate the significance of means for the water treatment $x$ endophyte status interaction $(P \leq 0.05)$. Different capital letters in each row indicate a significant water treatment effect $\mathrm{P} \leq 0.05$. $\mathrm{E}$ - and $\mathrm{E}+$ denote endophyte-free and endophyte-infected, respectively. 
Christensen 1982) used to confirm the endophyte status of each plant after the fungicide treatment. Fungicide treated plants were grown in a glasshouse for several weeks before being transferred into the pots.

\section{Irrigation records}

For the first two months, all plants were watered as required (approx. $400 \mathrm{ml}$ applied to the soil surface daily) to allow plants to fully establish (plants were considered fully established when tiller number reached a steady state). On 26 November, all drums were filled with water to $15 \mathrm{~cm}$ from the rim of the drum and the water was kept in the drums for 48 hours to allow percolation upwards through the soil profile in each pipe. Water was then drained out of the drums. From that date, the control drums were filled with water every three to four days as described above. The drums of the drought treatment groups received a limited water supply; over an interval of forty days $200 \mathrm{ml}$ of water was applied to the soil surface twice and drums were once half-filled with water (i.e. to $45 \mathrm{~cm}$ from the soil surface), and then drained after 24 hours.

\section{Measurements}

The predawn leaf water potential (LWP) was measured on 2 January 2013 between 5am and 7.30am using a Scholander pressure chamber (Scholander et al. 1965). The youngest fully expanded leaf of a randomly selected adult tiller was used to determine LWP. The lower 1 $\mathrm{cm}$ of the same leaf was cut and immediately wrapped in plastic cling film and tin foil, immersed in liquid nitrogen, and frozen at $-80^{\circ} \mathrm{C}$ for later measurement of osmotic potential (OP) with a thermocouple psychrometer (Wescor HR 33T). Leaf turgor pressure (TP) was estimated as the difference between LWP and OP. Relative water content (RWC) was determined using the procedure described by Bayat et al. (2009) with some modifications made (tubes were stored in weak light rather than in the dark to reduce respiration loss of $\mathrm{CO}_{2}$ ) based on the precautions proposed by Turner (1981). Pots were weighed on 3 and 4 January 2013 and daily water uptake was calculated from the loss of weights for each pot.

Destructive harvesting was carried out from 8 to 11 January 2013. At harvest, above ground herbage was divided into two components: green shoot $(>5 \mathrm{~cm}$ from the soil surface) and stubble $(0-5 \mathrm{~cm})$. The internal sleeve was pulled out from the pot and cut into three segments with its enclosed soil (D1 0-30 cm; D2 30-60 cm; D3 60-100 cm). For each soil depth visible roots (coarse roots) were extracted by hand and soil samples of approximately $500 \mathrm{~g}$ were weighed and dried at $105^{\circ} \mathrm{C}$ for 24 hours to determine gravimetric soil water content (SWC). The DM of green shoot, stubble and coarse root fractions from each soil depth were determined by oven drying at $80^{\circ} \mathrm{C}$ for 48 hours. An index for increased allocation of biomass to formation of deep roots was obtained by adding together both above ground mass and the soil D1 root mass and expressing this as denominator of a ratio with root mass

Table 2 Effects of water treatment, and water treatment interaction with endophyte status on relative water content (RWC), leaf water potential (LWP), osmotic potential (OP) and turgor pressure (TP).

Note: The standard deviations (SD) of means are shown in brackets. Small letters in each row indicate the significance of means for the water treatment $x$ endophyte status interaction $(P \leq 0.05)$. Different capital letters in each row indicate a significant water treatment effect $\mathrm{P} \leq 0.05$. $\mathrm{E}$ - and $\mathrm{E}+$ denote endophyte-free and endophyte-infected, respectively.

\begin{tabular}{|c|c|c|c|c|}
\hline & \multicolumn{4}{|c|}{ Water treatment } \\
\hline & \multicolumn{2}{|c|}{ Control } & \multicolumn{2}{|c|}{ Stress } \\
\hline & E- & $\mathrm{E}+$ & E- & $\mathrm{E}+$ \\
\hline \multirow[t]{2}{*}{ RWC (\%) } & $\begin{array}{c}96.5 \mathrm{a} \\
(5.7)\end{array}$ & $\begin{array}{c}94.8 \mathrm{a} \\
(3.8)\end{array}$ & $\begin{array}{l}82.0 \mathrm{~b} \\
(17.6)\end{array}$ & $\begin{array}{c}91.1 \mathrm{ab} \\
(7.0)\end{array}$ \\
\hline & \multicolumn{2}{|c|}{$95.7(4.8) \mathrm{A}$} & \multicolumn{2}{|c|}{ 86.6 B (13.8) } \\
\hline \multirow[t]{2}{*}{ LWP (bars) } & $\begin{array}{l}-2.6 \mathrm{a} \\
(1.0)\end{array}$ & $\begin{array}{c}-4.5 \mathrm{ab} \\
(2.3)\end{array}$ & $\begin{array}{c}-12.9 \mathrm{c} \\
(8.5)\end{array}$ & $\begin{array}{c}-8.5 b c \\
(3.7)\end{array}$ \\
\hline & \multicolumn{2}{|c|}{$-3.5(2.0) \mathrm{A}$} & \multicolumn{2}{|c|}{-10.7 B (6.8) } \\
\hline \multirow[t]{2}{*}{ OP (bars) } & $\begin{array}{c}-20.16 \mathrm{a} \\
(4.89)\end{array}$ & $\begin{array}{c}-28.05 \mathrm{ab} \\
(15.72)\end{array}$ & -37.09 b (16.92) & $-32.44 a b(14.18)$ \\
\hline & \multicolumn{2}{|c|}{$-24.11(12.00) \mathrm{A}$} & \multicolumn{2}{|c|}{-34.77 B (15.33) } \\
\hline \multirow[t]{2}{*}{ TP (bars) } & $\begin{array}{c}17.54 \mathrm{a} \\
(5.00)\end{array}$ & $\begin{array}{c}23.58 \mathrm{a} \\
(15.58)\end{array}$ & $\begin{array}{c}24.18 \mathrm{a} \\
(19.84)\end{array}$ & $\begin{array}{c}23.97 \mathrm{a} \\
(13.41)\end{array}$ \\
\hline & \multicolumn{2}{|c|}{$20.56(11.65) \mathrm{A}$} & \multicolumn{2}{|c|}{$24.08 \mathrm{~A}(16.43)$} \\
\hline
\end{tabular}

Note: The standard deviations (SD) of means are shown in brackets. Small letters in each row indicate the significance of means for the water treatment $x$ endophyte status interaction $(P \leq 0.05)$. Different capital letters in each row indicate a significant water treatment effect $\mathrm{P} \leq 0.05$. E- and $\mathrm{E}+$ denote endophyte-free and endophyte-infected, respectively. 
from soil D2 and D3 as numerator.

The rate of photosynthesis $\left(\mathrm{Pn} ; \mu \mathrm{mol} \mathrm{CO}_{2} \mathrm{~m}^{2}\right.$ leaf $\mathrm{s}^{-1}$ ), transpiration rate (Trans; $\mathrm{mmol} \mathrm{H}_{2} \mathrm{O} \mathrm{\textrm {m } ^ { 2 }}$ leaf $\mathrm{s}^{-1}$ ), stomatal conductance $\left(\mathrm{Gs} ; \mathrm{mmol} \mathrm{H}_{2} \mathrm{O} \mathrm{m}^{2}\right.$ leaf $\mathrm{s}^{-1}$ ) and leaf temperature $\left(\mathrm{LT} ;{ }^{\circ} \mathrm{C}\right)$ of the youngest fully expanded leaves of three randomly selected adult tillers in two replicates were measured for each entry, between 9:00 and 11:00 am, using a portable photosynthesis system (Li6400, LiCor Inc., USA) fitted with standard $2 \times 3 \mathrm{~cm}$ leaf chamber, leaf thermocouple and a blue-red LED light source. Instantaneous water use efficiency (iWUE) was estimated from the ratio of $\mathrm{Pn}$ and Gs (Osmond et al. 1980).

\section{Statistical analysis}

Data analysis was carried out with the Minitab 16 statistic software package. The General Linear Model (GLM) command was used for analysis of variance (ANOVA) of the data. Each variable was analysed in isolation from other variables, and the design was treated as a factorial combination of cultivar, endophyte status, and water treatment. Differences between means were assessed for significance $(\mathrm{P} \leq 0.05)$ using One-way Multiple Comparisons with Fisher's Least Significant Difference (LSD) method.

\section{Results and Discussion}

\section{Water treatment effects}

As expected, the SWC under drought stress was significantly $(\mathrm{P} \leq 0.05)$ decreased compared with well watered (control) plants in each of the soil layers (Table 1). The average value of predawn LWP under drought stress $(-10.7$ bars $)$ indicated that the drought severity was moderate.

During drought stress, both LWP and OP decreased significantly $(\mathrm{P} \leq 0.05) \quad(-10.7 \pm 6.8$ bars and $-34.77 \pm$ 15.33 bars $)$ compared with control group $(-3.5 \pm 2.0$ bars and $-24.11 \pm 12.00$ bars) (Table 2), and as a result TP remained comparatively unchanged (Table 2). This was a function of osmotic adjustment, which is achieved through accumulation of solutes in the cytoplasm and vacuoles of plant cells, thus allowing cells to maintain TP (Turner \& Jones 1980). This response is one of the "dehydration tolerant strategies" described by Turner (1986).

\section{Cultivar effects}

Tall fescue was chosen to provide a contrast with the two ryegrass cultivars, since it has been reported that 'Grasslands Flecha' is tolerant to summer drought stress (Malinowski et al. 2005). The key point of difference among cultivars was that 'Flecha' had distinctive gas exchange characteristics. There was a significantly $(\mathrm{P} \leq 0.05)$ greater Gs of 'Flecha' when compared to the two ryegrass cultivars was associated with significantly $(\mathrm{P} \leq 0.05)$ greater $\mathrm{Pn}$ and Trans, and thus cooler LT (Fig. 1) regardless of water treatment. The genetically controlled higher Gs of 'Flecha' has also been reported for other ryegrass and fescue varieties of North African origin, e.g. 'Medea' ryegrass (Hussain 2013). However, the iWUE of 'Flecha' was significantly less than the two ryegrass cultivars. No water treatment or endophyte effects on gas exchange parameters were detected in any of the cultivars $(\mathrm{P}>0.05)$.

Stubble mass and deep-root allocation varied among cultivars. Ryegrass cultivars had significantly $(\mathrm{P} \leq 0.05)$ more stubble mass than 'Flecha'. 'Banquet II' and 'Flecha' had significantly $(\mathrm{P} \leq 0.05)$ more deep-root allocation than 'Alto' under well watered conditions, but the advantages of 'Banquet II' over 'Alto' disappeared under drought stress (Table 3). A greater deep-root allocation as in 'Flecha' represents a potential for increased water supply that might assist plant survival in drought conditions, but in the case of 'Flecha' the increased water supply was associated with a higher Trans, as mentioned above, so the two traits in combination tend to cancel each other.

\section{Endophyte effects}

In the present experiment, we did not observe effects

Table 3 Effects of cultivar, and cultivar interactions with water treatment on deep-root allocation calculated as: (aboveground mass + root mass from $0-30 \mathrm{~cm}$ soil)/ root mass below $30 \mathrm{~cm}$. Deep-root allocation was $\log _{10}$-transformed.

\begin{tabular}{lcccc}
\hline Cultivars & \multicolumn{3}{c}{ Deep-root allocation (logarithmic) } & Stubble mass (g) \\
\hline 'Banquet II' & Stress & \\
& $-1.327 \mathrm{ab}$ & $-1.749 \mathrm{bc}$ & $-1.54 \mathrm{~B}$ & $(0.53)$ \\
'Alto' & $(0.221)$ & $(0.673)$ & $-1.78 \mathrm{~B}$ & $11.19(3.17) \mathrm{A}$ \\
& $-1.889 \mathrm{c}$ & $-1.679 \mathrm{bc}$ & $(0.34)$ & \\
'Flecha' & $(0.325)$ & $(0.342)$ & $-1.11 \mathrm{~A}$ & $5.61(2.64) \mathrm{B}$ \\
& $-1.136 \mathrm{a}$ & $-1.089 \mathrm{a}$ & $(0.24)$ & \\
\hline
\end{tabular}

Note: Standard deviations of means are shown in brackets. Small letters beside means indicate the significance at $\mathrm{P} \leq 0.05$ of mean separations for the respective cultivar $\times$ water treatment interactions. Means with different capital letters in the column differ among cultivars (at $\mathrm{P} \leq 0.05)$. 
of endophyte on green shoot matter, tiller number or total plant mass (data not shown), but we did note a significant $(\mathrm{P} \leq 0.05)$ effect on deep-root allocation in all cultivars. Hesse et al. (2003), found that endophyteinfected plants had increased root dry weight and greater root:shoot ratio compared to endophyte-free plants. By contrast, in the present experiment the deeproot allocation (logarithmic) for endophyte-infected plants $(-1.64 \pm 0.55)$ was less than that of endophytefree plants $(-1.31 \pm 0.31)$, suggesting that deep-rooting is a complex response that is affected by multiple factors. It may therefore be difficult to produce plant breeding lines that display this response consistently in a range of environments.

Endophyte infection also affected plant water relations. More specifically, in the presence of endophyte, there was no significant reduction in the RWC, LWP and OP of plants under drought stress compared with the control group, whereas, the RWC, LWP and OP in endophyte-free plants reduced significantly under water deficit, with RWC decreased from $96.5 \%$ to $82.0 \%$, LWP decreased from -2.6 bars to -12.9 bars, and OP decreased from -20.16 bars to -37.09 bars (Table 2). However, the TP in both endophyteinfected and endophyte-free plants was not changed (Table 2), suggesting that endophyte-free plants needed to develop osmotic adjustment to maintain turgidity while endophyte-infected plants, being better hydrated, did not need to develop osmotic adjustment. Similarly, Hahn et al. (2008) also found that endophyte-infected plants were not responding to the same degree to water deficit as observed for endophyte-free plants. Those authors' results also indicated that endophyte-infected plants possessed better water conservation capacity than endophyte-free plants under the same degree of drought stress.

\section{Conclusions}

The main findings of this study were: i) osmotic adjustment was a common component of plant response to drought stress; ii) 'Grasslands Flecha' had greater stomatal conductance and also a greater proportion of biomass allocated to deep root than the two ryegrass cultivars under both well-watered and drought stressed situation; iii) Endophtyte-infected plants had less leaf dehydration than endophyte-free plants under moderate drought stress.

\section{ACKNOWLEDGEMENTS}

We thank S. Ray, L. Taylor, and L. Sylva of Massey University Plant Growth Unit for assistance with plant culture, K. Sinclair and C. Rawlingson for laboratory assistance and U. Habib and A. Saleem for assistance with root extraction.

\section{REFERENCES}

Bayat, F.; Mirlohi, A.; Khodambashi, M. 2009. Effects of endophytic fungi on some drought tolerance mechanisms of tall fescue in a hydroponics culture. Russian Journal of Plant Physiology 56: 510-516.

Cheplick, G. P. 2004. Recovery from drought stress in Lolium perenne (Poaceae): are fungal endophytes detrimental? American Journal of Botany 91: 1960-1968.

Clark, D.A. 2011. Changes in pastoral farming practices and pasture persistence - a review. Pasture persistence symposium. Grassland Research and Practice Series 15: 7-13.

Clarke, J.M.; Durley, R.C. 1981. The responses of plants to drought stress. pp. 89-139. In: Water stress on plants. Ed. G.M. Simpson, G.M. Praeger Publishers, New York.

Hahn, H.; McManus, M. T.; Warnstorff, K.; Monahan, B. J.; Young, C. A.; Davies, E.; Tapper, B. A.; Scott, B. 2008. Neotyphodium fungal endophytes confer physiological protection to perennial ryegrass (Lolium perenne L.) subjected to a water deficit. Environmental and Experimental Botany 63: 183-199.

Hesse, U.; Schoberlein, W.; Wittenmayer, L.; Forster, K.; Warnstorff, K.; Diepenbrock, W.; Merbach, W. 2003. Effects of Neotyphodium endophytes on growth, reproduction and drought-stress tolerance of three Lolium perenne L. genotypes. Grass and Forage Science 58: 407-415.

Hussain, S. 2013. Drought tolerance mechanisms in "Mediterranean" perennial ryegrass (Lolium perenne L.) and potential for introgression of "Mediterranean" germplasm into New Zealand commercial cultivars. $\mathrm{PhD}$ thesis. Massey Univeristy.

Kane, K. H. 2011. Effects of endophyte infection on drought stress tolerance of Lolium perenne accessions from the Mediterranean region. Environmental and Experimental Botany 71: 337-344.

Latch, G.C.M.; Christensen, M.J. 1982. Ryegrass endophyte, incidence and control. New Zealand Journal of Agricultural Research 25:443-448.

Malinowski, D.P.; Belesky, D.P. 2000. Adaptations of endophyte-infected cool-season grasses to environmental stresses: Mechanisms of drought and mineral stress tolerance. Crop Science 40: 923-940.

Malinowski, D. P.; Zuo, H.; Kramp, B. A.; Muir, J. P.; Pinchak, W. E. 2005. Obligatory summerdormant cool-season perennial grasses for semiarid environments of the Southern Great Plains. Agronomy Journal 97: 147-154

Matthew, C.; Horne, D.J.; Baker, R.D. 2010. Nitrogen loss: an emerging issue for the ongoing evolution of New Zealand dairy farming systems. Nutrient Cycling in Agroecosystems 88: 289-298. 
Osmond, C.B.; Bjorkman, O.; Anderson, D.J. 1980. Physiological processes in plant ecology. Toward a synthesis with Atriplex. Springer-Verlag, New York.

Parsons, A.J.; Edwards, G.R.; Newton P.C.D.; Chapman D.F.; Caradus J.R.; Rasmussen, S.; Rowarth, J.S. 2011. Past lessons and future prospects: plant breeding for yield and persistence in cool-temperature pasture. Grass and Forage Science 66: 153-172.

Popay A.J.; Hume D.E. 2011. Endphytes improve ryegrass persistence by controlling insects. Pasture persistence symposium.Grassland Research and Practice Series 15: 149-156.

Scholander, P.F.; Hammel, H.T.; Bradstre, E.D.; Hemmings, E.A. 1965. Sap pressure in vascular plants - negative hydrostatic pressure can be measured in plants. Science 148: 339-346.
Simpson, W.R.; Schmid, J.; Singh, J.; Faville, M.J.; Johnson, R.D. 2012. A morphological change in the fungal symbiont Neotyphodium lolii induces dwarfing in its host plant Lolium perenne. Fungal Biology 116: 234-240.

Turner, N.C.; Jones, M.M. 1980. Turgor maintenance by osmotic adjustment: a review and evaluation. pp 87-103. In: Adaption of plants to water and high temperature stress. Eds. Turner, N.C.; Kramer, P.J. John Wiley and Sons, Inc., New York.

Turner, N.C. 1981. Techniques and experimental approaches for the measurement of plant water status. Plant and Soil 58: 339-366.

Turner, N.C. 1986. Adaptation to water deficits: a changing perspective. Australian Journal of Plant Physiology 13: 175-190. 